Бондарець Є. Дослідження й атриьуція ікони Благовішення ...

УДК [726.591+246.5](477-25)«16/18»

DOI https://doi.org/10.24919/2308-4863/34-1-5

Свгеній БОНДАРЕЦЬ, orcid.org/0000-0001-6534-382X

аспірант кафедри мистецтвознавчої експертизи Начіональної академії керівних кадрів культури і мистеитвв (Kuїв, Україна) ebondarets@dakkkim.edu.ua

\title{
ДОСЛІДЖЕННЯ Й АТРИБУЦІЯ ІКОНИ БЛАГОВІЩЕННЯ ПРЕСВЯТОЇ БОГОРОДИЦІ КІНЦЯ ХVIII - ПОЧАТКУ ХІХ СТ. У СРІБНОМУ ОКЛАДІ 1865 Р. КИЇВСЬКОГО МАЙСТРА І. ВІННИКОВСЬКОГО
}

Проблеми вивчення пізнього українського іконопису, переважно пам'яток кіния XVIII-XIX ст., дуже актуальні, оскільки тогочасні твори все ще мало досліджені та навіть не систематизовані. Це явище можна пояснити дослідницькими вподобаннями багатьох вчених, чиї прачі зосереджені на вивченні сакрального малярства більш ранніх часів.

Велика кількість абсолютно різних за стилем, технікою та матеріалами ікон зазначеного періоду робить неймовірно важкою навіть їх первинну класифікацію і систематизацію.

В українському сакральному живописі кінця XVIII-XIX ст. можна простежити два основні напрями, щзо відповідали запитам, сочіальному становищу і рівню свідомості замовників ікон. Значну частину за обсягом створення становили дешеві, так звані «народні ікони». Вони побутували переважно серед селянського населення $i$ не мали достатньої художньої якості. Дешеві ікони, які задовольняли селян, не відповідали естетичним смакам представників більш забезпечених верств суспільства. Поширення світського живопису сприяло сприйняттю ікони як реалістичного портрета святого або як документа, котрий фіксує ту чи іншу подію священної історії, щьо створювало умови для іконописних замовлень у майстрів, які мали професійну художню освіту. Професійні художники зазвичай працювали в актуальному загальному руслі стилістичного розвитку живопису свого часу.

Стаття присвячена атрибуиї ікони Благовіщення Пресвятої Богородиці у срібній золоченій ризі, щчо походить із приватної київської колекиії. Атрибуція проводилася на основі комплексного живописно-стилістичного та техніко-технологічного досліджень. Допоміжну роль відігравали архівні дослідження та джерелознавчий аналіз. На основі отриманих результатів вдалося встановити, щчо ікона була написана в кінці XVIII - на початку ХІХ cm. на Київиині у традиціях пізнього бароко. Побудова композичії загалом і деталі досліджуваного ізводу сходить до західноєвропейських гравюр із зображенням «Благовіщення із книгою», щяо були творчо переосмислені на національному трунті. Срібний оклад до ікони був виготовлений у 1865 р. видатним київським золотарем I. Вінниковським. Структурні та стилістичні особливості досліджуваної шати характерні для ювелірно-культового мистецтвв так званого «другого бароко» середини ХIX $\mathrm{cm}$.

Представлена пам'ятка може бути використана як рідкісний високохудожній зразок для подальшого системного вивчення іконописних традицій і ювелірного культового мистеитва Київщини.

Одержані результати актуальні та важливі для розуміння розвитку української ікони, вони можуть бути використані для класифікації та атрибуиії ікон кіния XVIII - початку XIX cm. Результати техніко-технологічного аналізу допоможуть у проведенні реставрації ікон, виконаних у тотожній техніці. Отримані дані можна застосувати в музейній практиці під час каталогізації фондів і вирішення питань атрибуиії ікон.

Ключові слова: украӥнська ікона, атрибуція, іконографія, Благовіщення Пресвятої Богородиці, ювелірне мистеитво, оклад, Київ.

Yevhenii BONDARETS, orcid.org/0000-0001-6534-382X Postgraduate Student at the Department of History of Art National Academy of Culture and Arts Management (Kyiv,Ukraine) ebondarets@dakkkim.edu.ua

\section{RESEARCH AND ATTRIBUTION OF THE ICON OF THE ANNUNCIATION OF THE END OF XVIII - EARLY XIX C. IN THE SILVER OKLAD OF 1865 OF THE KYIV JEWELRY MASTER I. VINNIKOVSKY}

The issue of studying late Ukrainian icon painting, mainly monuments from late 18th - 19th centuries, are very relevant, since the works of this period are still little researched and not even systematized. This phenomenon can be explained by the research preferences of many scholars whose work focuses on the study of sacred painting in earlier times of our history. 
A large number of icons of the indicated period, completely different in style, technique and materials, makes it incredibly difficult even for their primary classification and systematization.

In the Ukrainian sacred painting of the late 18th - 19th centuries it is possible to trace two main directions which met inquiries, social position and level of consciousness of customers of icons. A significant part of the icons created during this time frame are cheap, so-called "folk icons". They were popular mainly among the peasant population and did not have sufficient artistic quality. Cheap icons, satisfying the peasants, did not coincide with their aesthetic tastes for the representatives of the wealthier strata of society. The spread of secular painting contributed to the perception of the icon as a realistic portrait of a saint or as a document fixing a particular event in sacred history, created conditions for icon painting orders from masters who had a professional artistic education. Professional artists usually worked in the current general mainstream of the stylistic development of painting of their time.

The article is devoted to the attribution of the icon of the Annunciation in a gilded silver oklad (private collection, Kyiv). Attribution was carried out on the basis of complex pictorial-stylistic and technical-technological researches. Archival research and source analysis played a supporting role. Based on the results obtained, it was established that the icon was painted in the late 18th-early 19th centuries in Kyiv region in traditions of the late Baroque. The construction of the composition as a whole and a number of details of the studied conclusion date back to Western European engravings depicting the "Annunciation with a Book", which were creatively rethought on a national basis. The silver oklad for the icon was made in 1865 by the outstanding Kyiv goldsmith I. Vinnikovsky. Structural and stylistic features of oklad are characteristic of the jewelry and cult art of the so-called "second baroque" of the middle of the 19th century.

The studied icon can be used as a rare highly artistic sample for further systematic study of icon-painting traditions and jewelry cult art of Kyiv region. The obtained results of the study are relevant and important for the completeness of the picture of the development of the Ukrainian icon, they can be used in the classification and attribution of icons of the late 18th-early 19th centuries.

The results of technical and technological analysis are important for the restoration of icons made in the same technique. The obtained data can be applied in museum practice in cataloging funds and solving issues of icon attribution.

Key words: Ukrainian icon, attribution, iconography, Annunciation, jewelry art, oklad, Kyiv.

Постановка проблеми. Сьогодні $є$ досить актуальним питання всебічного вивчення та включення до наукового обігу автентичних творів українського іконопису із приватних збірок із метою розширення, доповнення та корегування критеріїв атрибуції. Цікавим і рідкісним прикладом сакрального мистецтва Київщини є ікона Благовіщення Пресвятої Богородиці кінця XVIII початку XIX ст. у срібному окладі 1865 р. майстра I. Вінниковського, яка походить із приватної київської колекції (рис. 1).
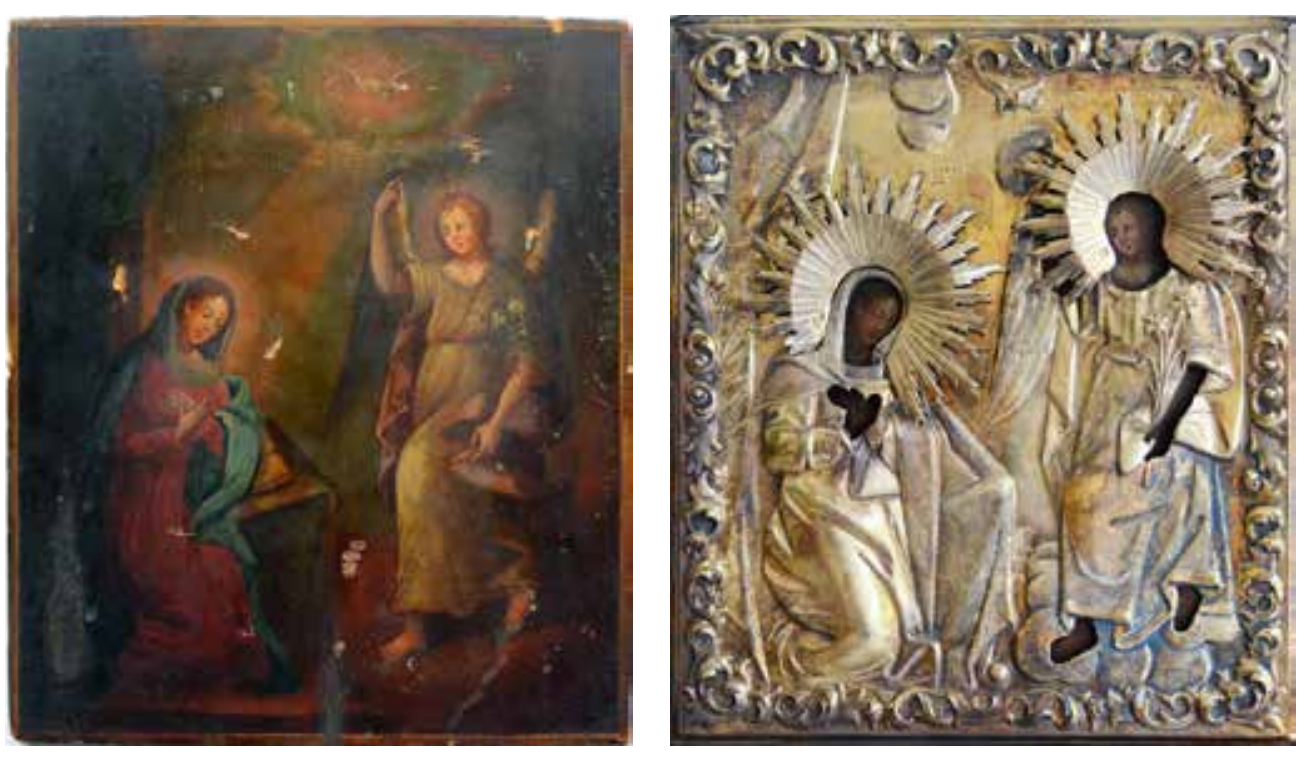

Рис. 1. «Благовіщення Пресвятої Богородиці», кінець XVIII - початок XIX ст., дерево, олія, 27,7x23,7x1,6 см; срібний оклад 1865 р. київського майстра

І. Вінниковського. Приватна колекція (Київ)
Мета статті полягає в дослідженні, атрибуції та введенні в науковий обіг вищезгаданої пам'ятки.

Аналіз досліджень. Хоча представлена ікона раніше не була об'єктом мистецтвознавчого дослідження, антропологія іконографічного образу Благовіщення Пресвятої Діви Марії досить добре вивчена. Загальні відомості про тексти, що послужили основою для зображення сцени Благовіщення, наведені у статтях Є. Барсова (Барсов, 1885: 107-109) та І. Порфир'єва (Порфир'єв, 1890: 142). 
Важливими для дослідження художньо-стильової еволюції іконографії цього образу стали праці Г. Герова (Геров, 2012: 189-198), В. Пуцко (Пуцко, 2008: 5-10), Л. Щенікової (Щенікова, 1999:246-263),І.Данилової(Данилова, 1977:39-47).

Вивченню іконопису Київщини присвячено багато публікацій. А. Кондратюк і Я. Литвиненко зібрали великий описовий та архівний матеріал, Л. Міляєва визначила богословську програму, О. Лопухіна й О. Пітателєва інтерпретували окремі іконографічні нюанси деяких сюжетів, виділили декілька груп ікон, об'єднаних за схожістю «авторського письма» (Пітателєва, 2003: 95), також О. Пітателева й А. Кондратюк окреслили проблематику подальших досліджень.

Історії українського ювелірного мистецтва та творчості видатного київського золотаря присвятили свої роботи Ж. Арустам'ян і М. Петренко.

Виклад основного матеріалу. Розмір дошки досліджуваної ікони - 27,7x23,7x1,6 см. Реставраційні втручання відсутні. На фарбовому шарі та дошці ікони наявні сліди побутування (забруднення, подряпини, відколи та вибоїни фарби, обпалення відкритим вогнем) (рис. 2). Мікроскопічний аналіз фактури фарбового шару та дослідження його в УФ-променях виявили первинне лакове покриття (без слідів пізніх втручань) (рис. 5).

Живопис ікони виконаний олійними фарбами на цільній липовій дошці, покритій тонким шаром грунту 3 коричнево-червоною імпріматурою (рис. 4). Тильна сторона дошки майстерно оброблена скобелем; наявні місця кріплення двох врізних зустрічних шпуг (втрачених) (рис. 3).

Традиційні іконні поля відсутні, середник обрамлений тонким охристим опушом. Сцена «Благовіщення про народження Сина Божого» відбувається у спочивальні Марії під час читання нею книги пророка Ісаї: «Се Діва в утробі зачне, i народить сина, і назвеш ім'я йому Еммануїл» (Ic. VII, 14). Посланий Богом архангел Гавриїл, вказуючи правицею на Святого Духа в небесному сяйві, демонструє Пресвятій Діві лівою рукою квітучу лілію - символ її непорочності та чистоти. Богородиця сприйняла неочікувану звістку архангела Гавриїла $з$ вираженою похвалою - стоячи на колінах зі схрещеними руками на грудях.

Лики святих дещо видовжені, 3 невеликими рисами, написані дрібними, роздільними мазками. На щоках і вустах лежить червоно-бузкова підрум'янка. Карнація світла. Дослідження фарбового шару в ІЧ-променях виявило нечіткий підготовчий вугільний малюнок (рис. 6). Одяг Пресвятої Діви Марії й архангела Гавриїла переданий досить виразно за рахунок підсиленої пишності та динамічного розподілу об'ємів драперії. Під час написання ікони іiі автор явно апелював до західноєвропейських гравюр, що є цілком характерним для творів доби українського бароко.

Колорит живопису ікони побудований на дзвінких фарбах, вміло збалансованих за допомогою ритмічного розподілу кольорів.

Досліджувана ікона прикрашена срібним карбованим позолоченим окладом, виготовленим із цільного листа, на якому монтовані вінці. Поєднання гладких площин, високого рельєфу драперії одягу святих, «гострих» променеподібних вінців і декоративних акантових мотивів полів характерне для ювелірно-культового мистецтва так званого «другого бароко» середини XIX ст.

На вінцях і нижній частини середника між фігурами Богородиці й Архангела розташовані клейма (у прямокутних щитках): ініціали прописні «IB»- клеймо київського майстра золотих

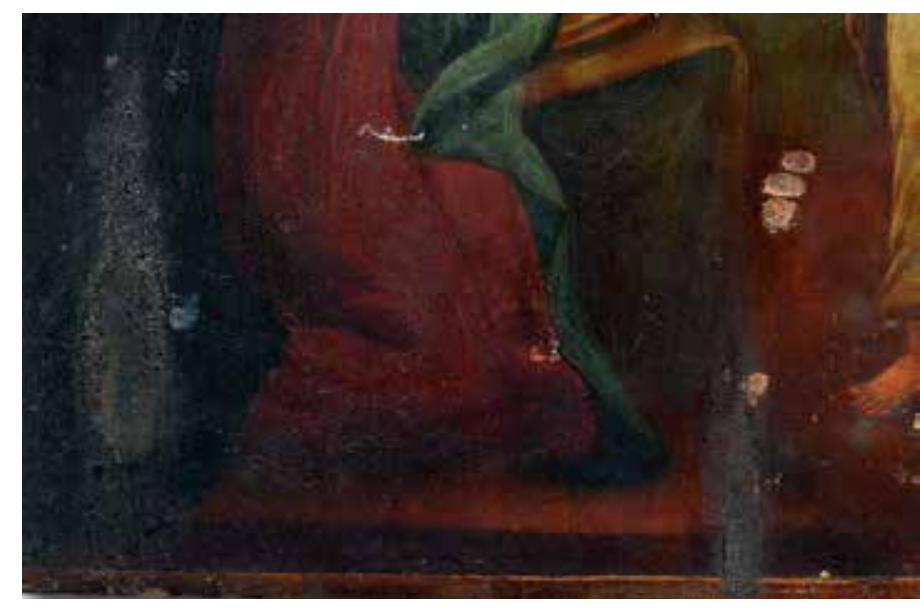

Рис. 2. Фрагмент із вираженими слідами побутування

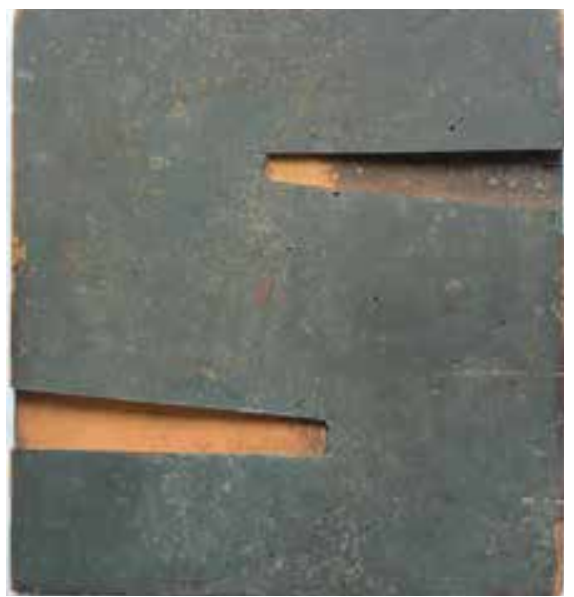

Рис. 3. Тильна сторона дошки 
і срібних справ першої половини - третьої чверті XIX ст. I. Вінниковського; 84 проба для виробів зі срібла; ініціали «?.Д» і дата 1865 р. - клеймо невідомого пробірного майстра; Архангел Михаїл із мечем і щитом, знизу дата 1865 р. - клеймо міста Києва (вик. 1848-1865) (рис. 7).

Із матеріалів біографії майстра Вінниковського Івана Васильовича відомо, що він жив у Києві у Фроловському провулку в будинку міщанина Дмитра Логвинова та мав майстерню, де працювали підмайстри й учні (Арустам'ян, 1996: 16). Серед його учнів було багато майбутніх відомих майстрів ювелірної справи: В. Француз, М. Бішевський, І. Хівренко, М. Богаєвський та ін. У 1823 р.
Іван Вінниковський був обраний до міської чиновницької комісії. У 1827 р. його запросили до однієї 3 найстаріших київських святинь - Софійського собору - для реставрації церковного начиння. Після закінчення робіт настоятель храму залишився дуже задоволений і вже через рік запросив Вінниковського знову, доручивши виготовити нові ризи для ікон. Із 1843 р. І.В. Вінниковський мав титул «Почесного громадянина» міста Києва. Більшість виробів майстра загинуло в часи Громадянської війни, вцілілі зберігаються в зібраннях Музею історичних коштовностей України та Національного художнього музею України (Арустам'ян, 1996: 18).

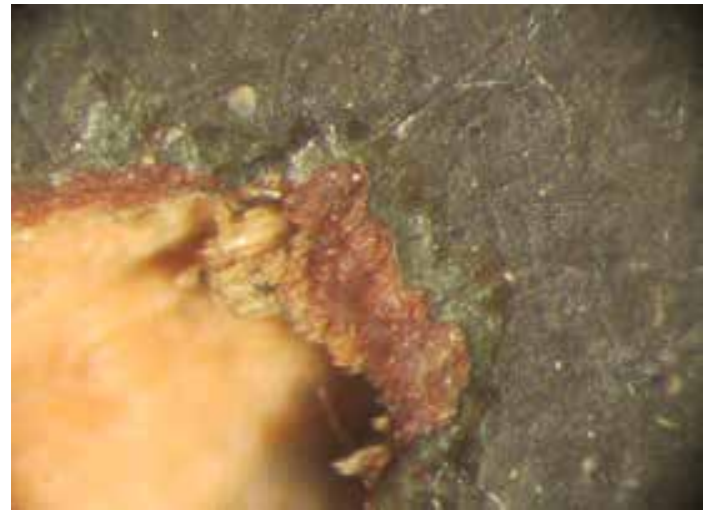

Рис. 4. Фрагмент сколу фарбового шару 3 мікроскопа МБС-10

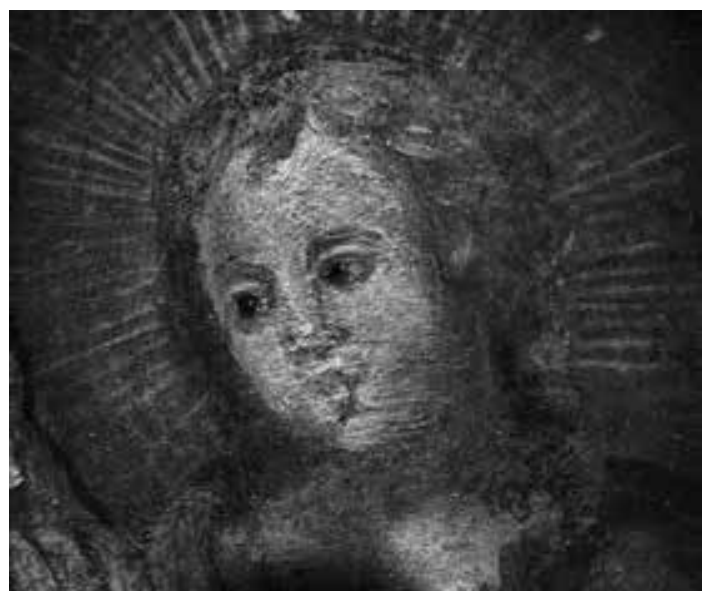

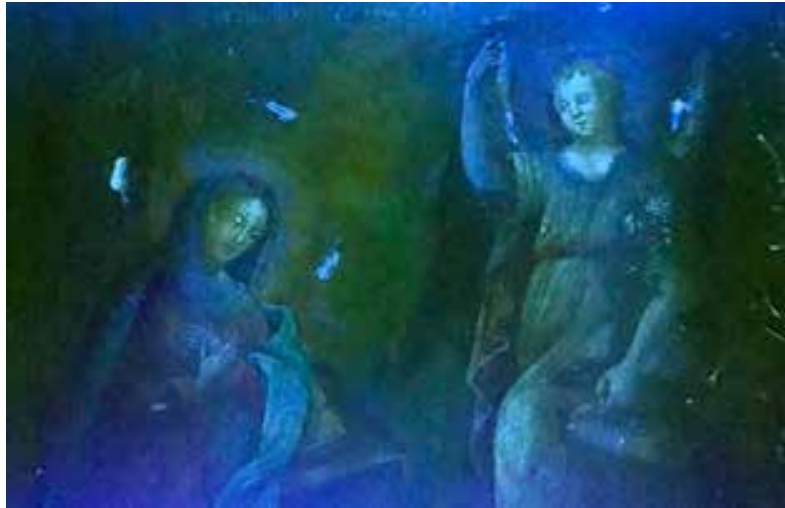

Рис. 5. Фрагмент фарбового шару в УФ-променях

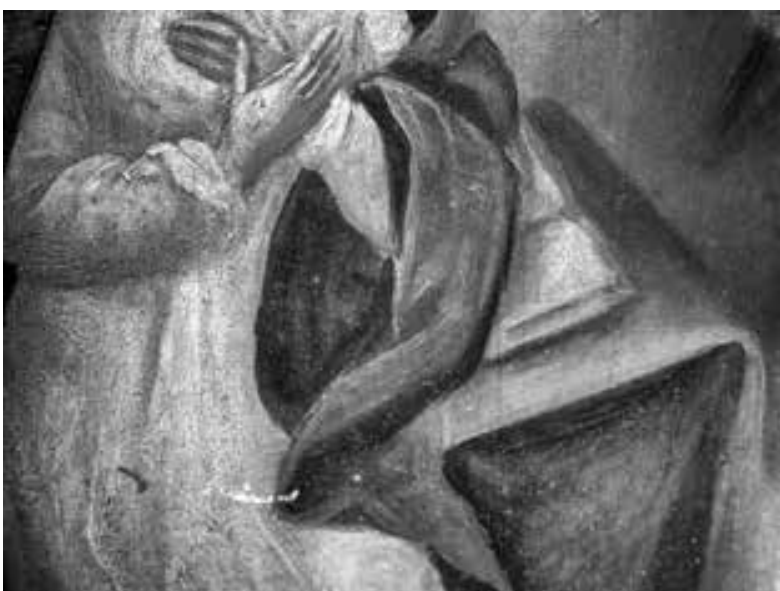

Рис. 6. Фрагменти живопису в ІЧ-променях
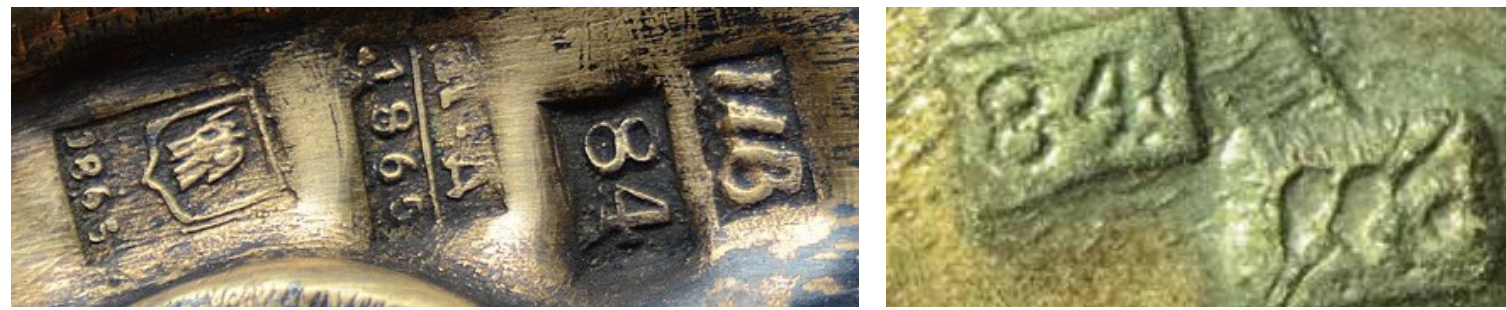

Рис. 7. Клейма на срібній ризі (вінцях і нижній частини середника) 
Бондарець Є. Дослілження й атриьуція ікони Благовішення ...

Благовіщення Пресвятої Богородиці має декілька іконографічних схем, що спираються на різні моменти цієї події або різні джерела її опису. Майстри протягом тисячоліть використовували як літературну основу канонічне Свангеліє від Луки, Протоєвангеліє Якова та Євангеліє Псевдо-Матвія.

Євангеліст Лука так описує подію Благовіщення: Гавриїл прийшов у Назарет до Діви Марії - дружини Йосипа із дому Давидового. Ангел, увійшовши до неї, сказав: «Радуйся, Благодатная! <..> ти в утробі зачнеш, і Сина породиш, і даси Йому ймення Ісус». Марія сказала: «Як же станеться це, коли мужа не знаю?». Цей дуже скупий опис надалі послугував основою для складання іконографії сцени «Благовіщення із пряжею», або «Другого Благовіщення». У такій композиції Марія зазвичай зображується в інтер'єрі із пряжею в руках згідно з текстом Протоєвангелія Якова (XI, 1), у якому Марія ткала за дорученням священиків завісу для єрусалимського храму. Іконографія композиції складається у V ст., причому поза ангела сходить до зображень вісника в античному мистецтві. Крила в ангела з'являються лише 3 V-VI ст.

Вірогідно, найбільш рання композиція Благовіщення знаходиться в катакомбах Прісцилли (III ст.), де у кріслі зображена сидяча жінка в туніці та палліумі, перед якою із жестом звернення зображений молодий чоловік у римському одязі. На равенському саркофазі V-VI ст. Марія сидить у кріслі, тримаючи веретено в руках, праворуч розташований крилатий ангел із посохом. Цей мотив розроблявся художниками протягом століть і добре відомий за зображеннями на мініатюрних мозаїках і фресках від Санта Марія Маджоре в Римі (432-445) до класичних образів у Дафні, Монреалі та Софії Київській (Геров, 2012: 193).

Іконографію «Благовіщення із пряжею» умовно можна розділити на кілька підвидів: коли Марія зображується стоячою (вперше на ампулі Монці, VI-VII ст.), під час зупинки прядіння, 3 піднятою головою і виставленою вперед долонею (відомі й інші ізводи, що розрізняються характером жестикуляції Маріі). Літературні джерела описують також сцену, що передувала основній появі архангела, - так зване «Перше Благовіщення», або «Благовіщення біля джерела». Одне 3 ранніх зображень ми зустрічаємо на окладі Свангелія зі слонової кістки (V ст.) у Міланському соборі. У центральній композиції окладу біля гірського джерела зображена стоячою навколішках перед архангелом Гавриїлом Діва Марія, яка тримає в лівій руці глечик. В XI-XII ст. художники часто перетворюють джерело в розкішний басейн (Сан-Марко у Венеції ХII ст., Софія Київська ХІ ст., Кахріє-Джамі в Константинополі, 1314 р.) (Геров, 2012: 195).

Слід зазначити, що у східнохристиянських пам'ятках часто присутнє зображення архангела, що спускається $з$ небес. Відома ікона «Устюзьке
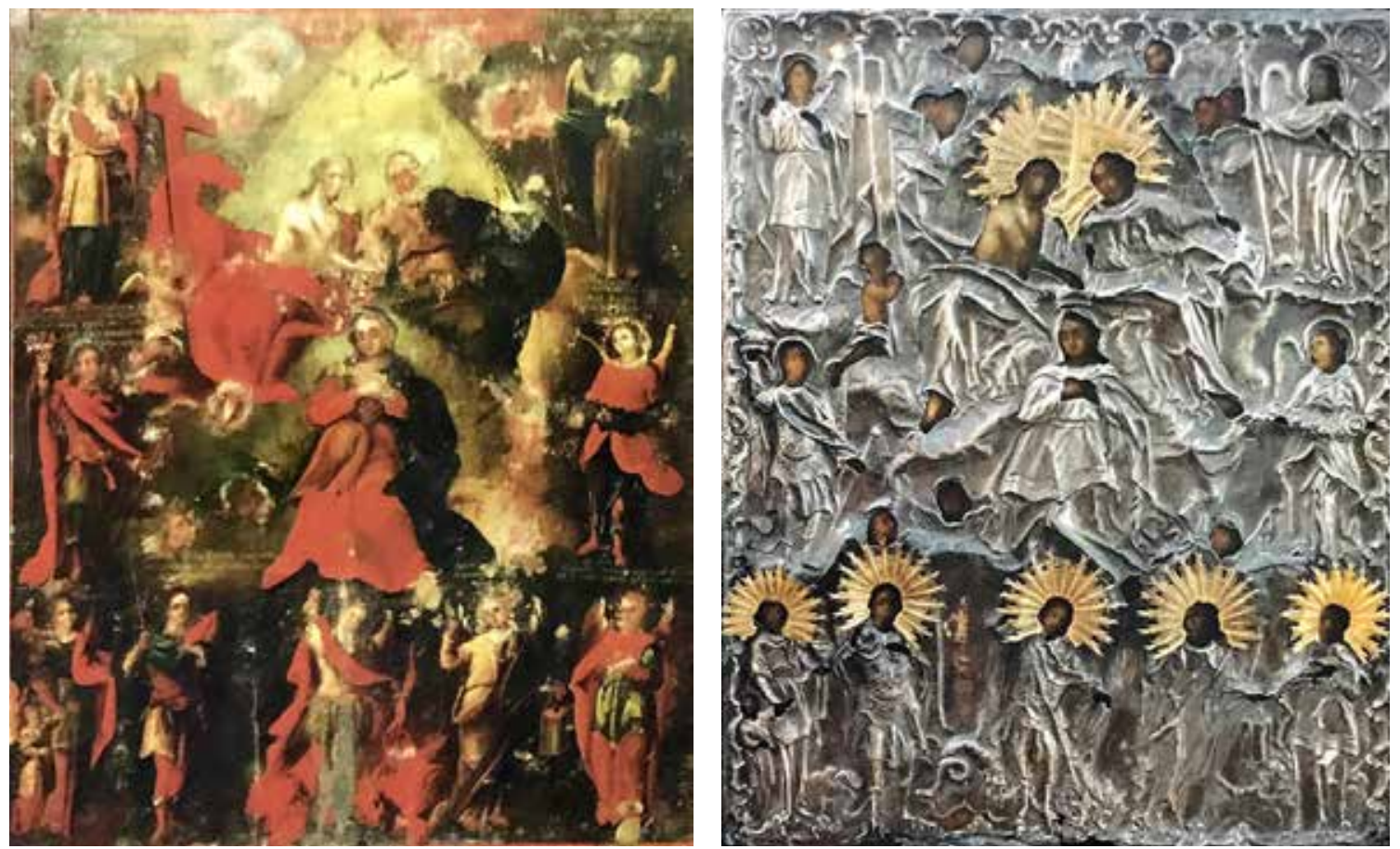

Рис. 8. «Коронування Пресвятої Богородиці», кін. XVIII ст., дерево, олія. 54x42,8x2,4 см. Колекція Л. Лихач (Київ) 
Благовіщення» (XII ст.) представляє третій, рідкісний тип Благовіщення із зображенням Немовляти в утробі. Іконографія цього ізводу виникла 3 метою наочної ілюстрації ідеї непорочного зачаття: «Син в персех у Пречистої вообразися мало знати, акі в склі» (Щенікова, 1999: 249). На грудях Марії, у медальйоні, зазвичай по пояс або в ріст зображується оголений малюк Христос. До медальйона йдуть промені від фігури Спаса, розташованого у яскравому сегменті у верхній частині композиції середника ікони. Марія в руках тримає веретено із пряжею. Цей ізвод стає особливо популярним у XVI-XVII ст., коли в російському іконописі наростає інтерес до подробиць.

У XVII ст. в давньоруському сакральному живописі поширюється тип «Благовіщення із книгою», відомий у західноєвропейських пам'ятках із XI ст. Зародки цього варіанту слід шукати у творах візантійської іконографії, а початковий літературний мотив - у Свангелії Псевдо-Матвія (6: 7-9). Звідси можна зробити припущення, що і в момент появи архангела Гавриїла Марія займалася читанням Святого Письма. Цілком імовірно, що це могла бути книга пророка Ісаї. Саме такий варіант описаний в іконописному оригіналі Г. Філімонова: «Пречиста сидить, а перед нею лежить книга розігнутая, а в ній написано: Ось діва в утробі зачне, і породить сина і даси ім'я йому Еммануїл» (Філімонов, 1873: 69).

Таким чином, можна сказати, що побудова композиції загалом і ряд деталей досліджуваного ізводу сходять до західноєвропейських гравюр із зображенням «Благовіщення із книгою», які були творчо переосмислені на національному грунті.

Досліджувана ікона має художньо-стилістичні аналоги в невеликому колі пам'яток київського походження. Особливо близьким $є$ образ «Коронування Пресвятої Богородиці» в пізній метале- вій ризі, виконаній в естетиці «другого бароко / рококо» середини XIX ст. (рис. 8).

Висновки. У процесі атрибуції зіставлялися технологічні прийоми та технічні засоби іконописця, отримані шляхом мікроскопічних досліджень, аналізу фактури фарбового шару а також вивчення живопису під впливом інфрачервоного й ультрафіолетового випромінювань. Отримані дані не суперечать орієнтовній за художньо-стильовими ознаками даті написання ікони, а саме кінцю XVIII - початку XIX ст.

Робота 3 архівними та бібліографічними джерелами дозволила встановити час, місце й автора срібного окладу досліджуваної ікони. Оклад був виготовлений у 1865 р. в Києві видатним золотих і срібних справ майстром першої половини - третьої чверті XIX ст. I. Вінниковським.

Іконографічні особливості ікони Благовіщення Пресвятої Богородиці вказують на те, що основними протографами для іконописця слугували переосмислені на національному грунті західноєвропейські гравюри із зображенням різновиду «Благовіщення із книгою», що є цілком характерним для іконопису Нового часу, особливо для українського сакрального малярства.

Художньо-стилістичні ознаки досліджуваного твору, а саме характер моделювання об'ємів, звучні фарби, вміло збалансовані за допомогою ритмічного розподілу кольорів, дотичні до загальних тенденцій іконопису Київщини доби пізнього бароко.

Таким чином, атрибутована та введена до наукового обігу ікона Благовіщення Пресвятої Богородиці кінця XVIII - початку XIX ст. у срібному окладі 1865 р. київського майстра I. Вінниковського може бути використана як рідкісний високохудожній зразок для подальшого системного вивчення іконописних традицій і ювелірного культового мистецтва Київщини.

\section{СПИСОК ВИКОРИСТАНИХ ДЖЕРЕЛ}

1. Арустам'ян Ж. Спадщина Івана Вінниковського - видатного київського ювеліра ХІХ ст. Пам'ятки декоративно-ужиткового мистецтва із колекиї Музею історичних коштовностей України - філіалу Національного музею історії України : збірник наукових праць. Київ, 1996. С. 16-18.

2. Арустам'ян Ж. Роль архівних документів у атрибуції виробів київського срібляра ХІХ ст. Івана Вінниковського. Архіви Украӥни. 2000. № 1/3. С. 66-69.

3. Барсов Е. О воздействии апокрифов на обряд и иконопись. Журнал Министерства народного просвещения. Санкт-Петербург, 1885. С. 107-109.

4. Данилова И. О византийской иконе XIV в. «Благовещение» из ГМИИ им. А.С. Пушкина. Античность. Средние века. Новое время. Москва : 1977. С. 39-47.

5. Кондратюк А. Досвід каталогізації зображень іконостаса Троїцької Надбрамної церкви Києво-Печерської лаври. Сіверщиина в історії Украӥни : збірник наукових праць. Суми, 2008. С. 109-113.

6. Литвиненко Я. Втрачені іконостаси лаврських церков. Лаврський альманах. 2010. Вип. 25. С. 67-86.

7. Лопухіна О. Іконографічна програма розписів Троїцької Надбрамної церкви як синтез богослов'я й мистецтва доби бароко. Лаврський альманах. 2002. Вип. 7. С. 119-127.

8. Міляєва Л. Українська ікона XI-XVIII століть : альбом. Київ, 2007. 528 с.

9. Петренко М. Українське золотарство XVI-XVIII. Київ : Наукова думка, 1970. 208 с. 
10. Пітателєва О. Особливості іконографії у двох іконах «Таємна вечеря» з іконостаса Троїцької Надбрамної церкви. Лаврський альманах. 2003. Вип. 11. С. 92-96.

11. Порфирьев. И. Апокрифические сказания о новозаветных лицах и событиях, но рукописям Соловецкой библиотеки. Санкт-Петербург, 1890. С. 142.

12. Пуцко В. Об одном иконографическом варианте «Благовещения». ХІІ научные чтения памяти И. Болотцевой (1944-1995) : сборник статей. Ярославль, 2008. С. 5-10.

13. Філімонов Г. Иконописный подлинник новгородской редакции по софийскому списку конца XVI века. Москва : Унив. тип. (Катков и К $\left.{ }^{\circ}\right), 1873.138$ с.

14. Щенникова Л. «Благовещение Устюжское». Благовещенский собор Московского кремля: Материаль и исследования. Москва, 1999. С. 246-263.

\section{REFERENCES}

1. Arustam'yan ZH. Spadshchyna Ivana Vinnykovs'koho - vydatnoho kyivs'koho yuvelira XIX st. [The legacy of Ivan Vinnikovsky - a prominent Kyiv jeweler of the XIX century]. Monuments of decorative and applied art from the collection of the Museum of Historical Treasures of Ukraine - a branch of the National Museum of History of Ukraine: temat. zb. nauk. pr. Kyiv, 1996. P. 16-18. [in Ukrainian].

2. Arustam'yan Zh. Rol arkhivnykh dokumentiv u atrybutsiyi vyrobiv kyivs'koho sriblyara XIX st. Ivana Vinnykovs'koho. [The role of archival documents in the attribution of the products of the Kiev silversmith of the XIX century of Ivan Vinnikovsky]. Archives of Ukraine. 2000. № 1/3. P. 66-69. [in Ukrainian].

3. Barsov E. O vozdeystvii apokrifov na obryad i ikonopis. [About the impact of the apocrypha on the rite and icon painting]. Journal of the Ministry of Public Education. St. Petersburg, 1885. P. 107-109. [in Russian].

4. Gerov G. Ob odnom iz variantov "Blagoveshcheniya" v iskusstve pozdnevizantiyskogo perioda. [About one of the variants of the "Annunciation" in the art of the late Byzantine period]. DRI. The art of medieval Russia and Byzantium of the era of Andrei Rublev. Edited by E. Smirnova. Moscow, 2012. P. 189-198. [in Russian].

5. Danilova I. O vizantiyskoy ikone XIV v. "Blagoveshcheniye" iz GMII im. A.S. Pushkina. [About the Byzantine icon of the XIV century "Annunciation" from the Pushkin Museum]. Antiquity. Middle Ages. New time. Moscow, 1977. P. 39-47. [in Russian].

6. Kondratyuk A. Dosvid katalohizatsiyi zberezhenyy ikonostasa Troyits'koyi Nadbramnoyi tserkvy Kyyevo-Pechers'koyi lavry. Sivershchyna v istoriyi Ukrayiny. [Experience of cataloging images of the iconostasis of the Trinity Gate Church of the Kiev-Pechersk Lavra]. Severshchyna in the history of Ukraine: a collection of sciences. Sumy, 2008. P. 109113. [in Ukrainian].

7. Lytvynenko J. Vtracheni ikonostasy lavrs'kykh tserkov. Lavrs'kyy al'manakh. [Lost iconostasis of Lavra churches]. Lavra Almanac. 2010. Issue. 25. P. 67-86. [in Ukrainian].

8. Lopukhina O. Ikonohrafichna prohrama rozpysiv Troyits'koyi Nadbramnoyi tserkvy yak syntez bohoslovya y mystetstva doby baroko. [Iconographic program of paintings of the Trinity Gate Church as a synthesis of theology and art of the Baroque era]. Lavra Almanac. 2002. Issue. 7. P. 119-127. [in Ukrainian].

9. Milyayeva L. Ukrayins'ka ikona XI-XVIII stolit'. [Ukrainian icon of XI-XVIII centuries]: album. Kyiv, 2007. 528 p. [in Ukrainian].

10. Petrenko M. Ukrayins'ke zolotarstvo XVI-XVIII. [Ukrainian goldsmith XVI-XVIII]. Kyiv: Scientific thought, 1970. 208 p. [in Ukrainian].

11. Pitatelyeva O. Osoblyvosti ikonohrafiyi u dvokh ikonakh “Tayemna vecherya” z ikonostasa Troyits'koyi Nadbramnoyi tserkvy. [Features of iconography in two icons "The Last Supper" from the iconostasis of the Trinity Gate Church]. Lavra Almanac. 2003. Issue. 11. P. 92-96. [in Ukrainian].

12. Porfiryev. I. Apokrificheskiye skazaniya o novozavetnykh litsakh i sobytiyakh, no rukopisyam Solovetskoy biblioteki. [Apocryphal legends about New Testament persons and events, but the manuscripts of the Solovetsky library]. St. Petersburg, 1890. P. 142. [in Russian].

13. Putsko V. Ob odnom ikonograficheskom variante "Blagoveshcheniya". [About one iconographic version of the "Annunciation"]. XII scientific readings in memory of I. Bolotseva (1944-1995): collection of works. Yaroslavl, 2008. P. 5-10. [in Russian].

14. Filimonov G. Ikonopisnyy podlinnik novgorodskoy redaktsii po sofiyskomu spisku kontsa XVI veka. [Iconographic original of the Novgorod edition according to the Sofia copy of the late 16th century]. Moscow: Univ. pub. (Katkov and $\mathrm{K}^{\circ}$ ), 1873. 138 p. [in Russian].

15. Shchennikova L. "Blagoveshcheniye Ustyuzhskoye". ["Annunciation of Ustyug"]. Annunciation Cathedral of the Moscow Kremlin: Materials and Research. Moscow, 1999. P. 246-263. [in Russian]. 